\title{
EARTHQUAKES AND DISTURBANCES TO LEVELING IN THE IMPERIAL VALLEY, 1930-1931*
}

\author{
By Harry O. WOOD
}

\begin{abstract}
COMPARISON in 1931 of the findings of field investigation in 1930 of the earthquakes of February 25 and March 1 of that year in the Imperial Valley, California, with disturbances to leveling found in the 1931 retracement of precise leveling surveyed in 1926-1927, and 1928 , by the U. S. Coast and Geodetic Survey led to the conclusion that there was no discernible correlation except in one instance, and that doubtful.

Occurrence of the 1940 earthquake with disclosure of a surface fault offset necessitates review and reconsideration. The revised conclusion is that two of the disturbances to leveling found in 1931 may probably be correlated with activity on this fault zone, but that the disturbances are quite as likely due to secondary effects caused by shaking as to primary surface warping or tilting and probably more so.

The necessity of frequently repeated precise surveys is emphasized.
\end{abstract}

IN 1930 two small destructive earthquakes, of intensity VIII $+(\mathrm{R}-\mathrm{F})$ - or VIII (1931 scale) approximately-occurred in the Imperial Valley, California, on February 25 at about 18:30 P.S.T. (6:30 P.M.), and on March 1 at about $15: 44$ P.S.T. ( $3: 44$ P.M.). ${ }^{1}$ Of these the first was somewhat the greater, both in intensity and in magnitude, but the second caused more damage because its source was located nearer to a larger center of population.

Immediately after their occurrence the effects of these shocks were investigated thoroughly in the field by the present writer. However, because of their small magnitudes, and for destructive shocks relatively low intensities, and because of the locations of their epicentral areas in the desert area to the west of the populated parts of the Valley, the findings of the field study were meager and did not appear to warrant extended formal publication. Nothing significant can be added to the brief accounts given in "United States Earthquakes, 1930," although information could be given at greater length and in more detail. Nevertheless these field findings did suffice to indicate that the origin of the shock on February 25 was near to the small cross-roads community of Westmorland and almost surely to the west and slightly to the south of it: also that the source of the shocks on March 1 was near the larger community of Brawley and to the west of that city. These indications were not of a wholly conclusive nature, but practically all of the meager evidence supported them and they are still considered sound. One discordant finding-surface earth disturbance and craterlets in plowed and cultivated ground north of Westmorland and west of Calipatria-was judged to be due to the loose and water-charged nature of the ground, and this judgment is still considered valid.

* Manuscript received for publication August 5, 1942.

1 "United States Earthquakes, 1930," U. S. Coast and Geod. Surv., Serial No. 589, pp. $9-10$ (1931). 
The instrumental determinations of the epicenters of these shocks also indicated locations to the west of Westmorland and Brawley, respectively. It should be stated, however, that these determinations are not judged to be highly exact, because the locations of the seismologic stations did not form a very satisfactory geographic pattern-with no near-by stations to the northeast or east, nor to the southward, and with the station at La Jolla out of order -and because the distances from the shock sources to the nearest stations were somewhat greater than is advantageous for local-earthquake determinations of desirable precision.

The course of the San Jacinto fault, projected to the southeastward from its previously proved active part, passes a short distance to the west of Westmorland and Brawley in the neighborhood of Superstition Mountain, which is believed to take its name from the occurrence of earth disturbances near by. It was therefore considered that the San Jacinto fault.was the probable source of the shocks, and that the field and instrumental findings were in good agreement with this, so far as meager field evidence and instrumental locations lacking in high precision could lend support to any hypothesis.

It should be recorded here that the late Maxwell $W$. Allen inquired of the writer shortly after the completion of the field study whether the shocks could have originated on a putative fault extending in a northwest-southeast direction along the southwestern shore of the Salton Sea. However, it should also be stated that Allen's inquiry was prompted entirely by a consideration of press reports of the shocks, and not at all on instrumental studies, studies of effects in the field, or geological studies of the field. In fact he was not well acquainted with the field. At that time no fault was definitely ${ }^{2}$ known such as that postulated in his inquiry. Moreover, after he had learned of the field and instrumental findings, he expressed himself as entirely satisfied with the conclusions stated in the immediately foregoing paragraph.

\section{LEVELING}

Between December 13, 1926, and March 5, 1927, a line of first-order levels was run by the U.S. Coast and Geodetic Survey between San Diego and Yuma

along the San Diego and Arizona Railway, through Tecate, Campo, and Jacumba, California; thence along the Bankhead Highway to Coyote Wells; thence along the San Diego and Arizona Railway to El Centro, California; thence along the Holtville Interurban Railway to Holtville, California; thence along the Bankhead Highway to a point about 8 or 9 miles west of Yuma, Arizona; and thenee along the Southern Pacific Railway to Yuma, Arizona.

The description just quoted is taken from an unpublished office report by Howard S. Rappleye to the Chief, Division of Geodesy, U. S. Coast and Geo-

${ }^{2}$ Such a fault had been suggested, but not strongly, by Beal in a study of the 1915 shocks in the Imperial Valley. 
detic Survey, on the subject "Releveling in Southern California," dated May 29,1931 . The immediately following quotation is also taken from this report.

On January 26, 1928, first order leveling was begun at El Centro, California, and extended along the Southern Pacific Railroad through Brawley and Niland, California, to Colton, California. This line was completed on March 22, 1928.

\section{RELEVELING}

After the occurrence of the earthquakes on February 25, and March 1, 1930, at the request of Dr. Arthur L. Day, then Chairman of the Advisory Committee in Seismology of the Carnegie Institution of Washington-again quoting from the Rappleye report:

a program of releveling was undertaken which called for the retracement of the old leveling from Niland, California, southward to EI Centro, California, and westward to Jacumba, California, and from El Centro, California, eastward to Yuma, Arizona. This releveling was begun at Niland on February 17, 1931, and the party completed the work to Jacumba on March 13, 1931. The releveling between El Centro and Yuma occupied the time from March 16 to 28, inclusive, of 1931.

Thus about one year elapsed between the occurrence of the earthquakes (and the field study of their effects) and the field work of the program of releveling. The Survey office work was carried out promptly and the office report was submitted on May 29, 1931. This report contains a brief statement concerning instructions and procedure in connection with the field work, some discussion of special circumstances encountered in the work and of expectable deviations between old and new findings where no extraneous disturbances had taken place, and mentions certain findings which will be quoted immediately below.

Some local disturbance is indicated in the locality of S-69 and R-69 but whether this is due to an earthquake or a change in the relation of the marks to the adjacent ground surface cannot be fully stated.

[Bench mark] S 69.-About 0.5 mile south of Niland, Imperial County, . . (139) ${ }^{3}$

[Bench mark] R 69.-About 2.5 miles south of Niland, Imperial County, . . (140)

New elevations tend to run increasingly lower than the old from Niland to bench mark H-69 near Brawley. From H-69 to G-69 and from G-69 to F-69 the new differences vary from the old by amounts all out of proportion to the errors to be expected in the leveling itself. The new elevations change suddenly from below to above the old elevations and the downward trend of the ragged line is again taken up and with minor variations continues to the vicinity of Plaster City.

[Bench mark] H 69.-At Brawley, Imperial County, at the corner of Imperial Avenue and $\mathrm{A}$ Street, in the wall of the Junior College, 15 feet west of the northeast corner and 4 feet above the ground. A standard disc, stamped "H 69 1928" and set in the wall. $(-33.364$ meters or -109.462 feet) (149)

[Bench mark] G 69.-About 1.5 miles south of Brawley, Imperial County, on the Southern Pacific Railroad, 3 poles north of milepost 688, 80 feet south of a crossing and 53 feet east of the center of the tracks. A standard disc, stamped "G 691928 " and set in the top of a concrete post. ( -33.501 meters or -109.911 feet). (151)

${ }^{3}$ The numbers in parentheses are the 1931 designations of these bench marks. 
[Bench mark] F 69.-About 4.9 miles north of Imperial, Imperial County, on the Southern Pacific Railroad, at the north end of the switch at Grape, 51 feet east of the center of the tracks and 32 feet north of a power line pole. A standard disc, stamped "F 691928 " and set in the top of a concrete post. ( -35.968 meters or -118.005 feet). (152)

At $\mathrm{G}-59$ and $\mathrm{F}-59$ some movement may be indicated but it is not particularly large and may be of no particular importance.

[Bench mark] G 59.-At Plaster City, Imperial County, on the San Diego and Arizona Railway, .... (171)

[Bench mark] F 59.-About 1.6 miles west of Plaster City, Imperial County, on the San Diego and Arizona Railway, . . . (172)

The condition of affairs at the group Y-58, X-58 and W-58 looks suspiciously like earth movement but is of such small size as to be in doubt.

[Bench mark] Y 58.-About 3.3 miles east of Mountain Springs, Imperial County, on the Bankhead Highway, . . . (179)

[Bench mark] X 58.-About 1.5 miles east of Mountain Springs, Imperial County, on the Bankhead Highway, . . . (180)

[Bench mark] W 58.-At Mountain Springs, Imperial County, on the Bankhead Highway, ... (181)

East of El Centro some disturbance certainly is indicated in the vicinity of Holtville but from A 60 eastward to Yuma there is little or no indication of any movement. The beautiful agreement between the old and new in the [this, H.O.W.] portion of the line seems to me to lend weight to the possibilities of detecting movement if such actually occurs.

[Bench mark] A 60.-About 4.9 miles east of Holt Avenue in Holtville, Imperial County, on the Bankhead Highway, ... (203)

Summarizing:-Earth movements or, at least, disturbances of the bench marks is clearly indicated in the portions of the line from

\section{S-69 to R-69 \\ G-69 to F-69 \\ W-59 to $Z-59$}

[Bench mark] W 59.-About 3 miles west of Holtville, Imperial County, on the Holton [Holtville, H.O.W.] Interurban Railway, 1 mile east of the Meloland Store, 300 feet west of a road crossing, at the north edge of the highway, in line with the row of power line poles and 45 feet south of the track. A standard disc, stamped "W 59 1927" and set in the top of a concrete post. ( -15.468 meters or -50.748 feet). (197)

[Bench mark] Z 59.-About 2.5 miles east of Holtville, Imperial County, on the Bankhead Highway, at the southeast corner of a road crossing, 45 feet east of the center of the Calexico road, and 65 feet south of the center of the road leading to Yuma. A standard disc, stamped ' $Z 591927$ ' and set in the top of a concrete post. ( -2.511 meters or -8.238 feet). (202)

It is also desirable to quote at this point the descriptions of bench marks $\mathrm{U}-59, \mathrm{~V}-59, \mathrm{X}-59,-10 \mathrm{Y}, \mathrm{J}-60$, and $\mathrm{Y}-59$, as follows:

[Bench mark] U 59.-About 2.9 miles east of El Centro, Imperial County, on the Holton [Holtville, H.O.W.] Interurban Railway, 200 feet west of a road crossing, at the north edge of the highway, 45 feet south of the track, and 12 feet east of a power line pole. A standard disc, stamped " $\mathrm{U} 591927$ " and set in the top of a concrete post. ( -15.044 meters or -49.357 feet). (193)

[Bench mark] V 59.-About 5 miles east of El Centro, Imperial County, on the Holton [Holtville, H.O.W.] Interurban Railway, 1 mile west of the Meloland store, 75 feet east 
of a road crossing, in line with some power line poles, 45 feet south of the track and at the north edge of the highway. A standard dise, stamped "V 59 1927" and set in the top of a concrete post. ( -16.613 meters or -54.504 feet). (196)

[Bench mark] X 59.-About 1 mile west of Holtville, Imperial County, on the Holton [Holtville, H.O.W.] Interurban Railway, 100 feet west of a road crossing, at the north edge of the highway, in line with the row of power line poles and 45 feet south of the track. A standard disc, stamped "X 59 1927" and set in the top of a concrete post. ( -7.360 meters or -24.147 feet). (198)

[Bench mark] -10Y (U.S.G.S.).-At Holtville, Imperial County, at the corner of Fifth Street and Holt Avenue, in the east face of the northeast corner of the Holtville Bank, in the Alamo Hotel building, 4 feet above the sidewalk and $2 \frac{1}{2}$ feet south of the corner. A U. S. Geological Survey standard disc, stamped "-10Y." ( -2.644 meters or -8.665 feet).

Note:-This tablet was originally stamped " $-12 Y$ " but was moved about 1922 and replaced after alterations were made to the bank. The elevation given above applies to the mark as it was situated in 1927. (199)

[Bench mark] J 60.-At Holtville, Imperial County, on the Holton [Holtville, H.O.W.] Interurban Railway, 40 feet east of the station, outside of a fence corner at the edge of the sidewalk on the west side of Holt Avenue, and 85 feet north of the main track. A standard dise, stamped " $\mathrm{J} 601927$ " and set in the top of a concrete post. ( -4.270 meters or -14.009 feet). (200)

[Bench mark] Y 59.-About 1 mile east of Holt Avenue in Holtville, Imperial County, on the Bankhead Highway, at the south edge of the highway right of way, 45 feet east of a ditch and 10 feet east of a road leading to a farmhouse. A standard disc, stamped "Y 59 1927" and set in the top of a concrete post. ( -2.985 meters or -9.793 feet). (201)

Besides the brief text from which the foregoing quotations are made, this office report contains, as appendices, a tabulation of "Observed DifferenceObserved Elevation," a blueprint "Profile of Line" and "Diagram showing divergence of 1931 leveling with relation to that of 1927 and 1928," a blueprint "Sketch Map Showing Releveling in Southern California-1931" which exhibits the course of the lines of the releveling and the positions of the bench marks reoccupied, and a list of descriptions of the bench marks occupied in 1926-1927 and in 1928 which includes, and identifies, those reoccupied in 1931. (The descriptions quoted are taken from this list.)

\section{Correlation}

A copy of this office report was made available to the present writer shortly after its completion. The places where there appeared to be disturbance, or possible disturbance, to the leveling between the 1926-1927 and 1928 surveys and that of 1931 were carefully considered in the light of the findings of the earthquake field investigation of the previous year, with the following conclusions.

1) There was no discernible correlation between the seismic effects noted in the field and the disturbance to the level line immediately south of Niland in the locality of S-69 to R-69; nor with "the group Y-58, X-58, and W-58" at Mountain Springs and for a distance of a little over three miles to the east of that point. 
2) In the light of any knowledge then available--there was no discernible correlation between the seismic effects seen in the field and the disturbance to the line of levels in the vicinity of Holtville, from "W-59 to Z-59."

3) The disturbance of levels at Plaster City, and for a little more than a mile and a half westward from that place, could just possibly have been caused directly by surface warping or tilting due to activity upon the southeastward prolongation of the San Jacinto fault, whose surface outcrop is not known exactly where it traverses the sand and alluvium of the southwest part of Imperial County. However, this was considered very doubtful because the location of the disturbance to the leveling probably is considerably to the west of the course of the fault, and in any event it was commented upon as "not particularly large and may be of no particular importance." Also there was the possibility that such a change in levels might be due to earth shaking, and not to any direct surface distortion caused by fault slipping. On the whole, at this locality any correlation between level disturbance and surface distortion due directly to faulting appeared very dubious.

4) The disturbance to the leveling found at Brawley, and for a short distance to the south, "between G-69 and F-69," appeared to denote a genuine change. This location, however, definitely lay well to the east of any reasonable southeastward projection of the San Jacinto fault. It traversed a water-charged, irrigated, alluvial area at a short distance east of the course of the New River. And it was in the central district shaken with moderate violence by the shock of March 1, 1930. The most reasonable conclusion seemed to be that here a genuine disturbance to the leveling had been caused by secondary ground distortion due to shaking. Ground buckling in the vicinity of river banks is a well-known effect of strong earthquakes.

The conclusions stated in the foregoing four paragraphs were reached in 1931, and in the light of the knowledge then available they are still considered well judged. Since the chief purpose of the retracement of the leveling was to detect surface distortion due to the accumulation of strain, or its release in the production of faulting, there appeared to be no occasion for the publication of this study made by the present writer in 1931. Nothing more than vague conjectures as to possible correlation of the observed seismic effects with primary earth distortion could have been presented at that time.

\section{Later Evidence}

However, the occurrence of the earthquake of May 18, 1940, with the surface fault trace then disclosed, necessitates reconsideration. ${ }^{4}$

This fault has been mapped and described briefly by F. P. Ulrich, ${ }^{5}$ and will

\footnotetext{
${ }^{4}$ In the course of a long illness the unpublished office report upon the releveling, by Rappleye, became mislaid, and it has only recently become available, affording opportunity for recomparison.

5 Franklin P. Ulrich, "The Imperial Valley Earthquakes of 1940," Bull. Seism. Soc. Am., 31:13-31 (January, 1941).
} 
be discussed further in a forthcoming paper by J. P. Buwalda and C. F. Richter, who made intensive studies of it in the field. Its course, north of the international boundary between Mexico and the United States, is shown on the accompanying map (fig. 1). It runs definitely to the east of the projected course of the San Jacinto fault.

At a first glance it is obvious that the disturbances to the lines of levels at and just south of Brawley, and to the west of Holtville, are near the course of

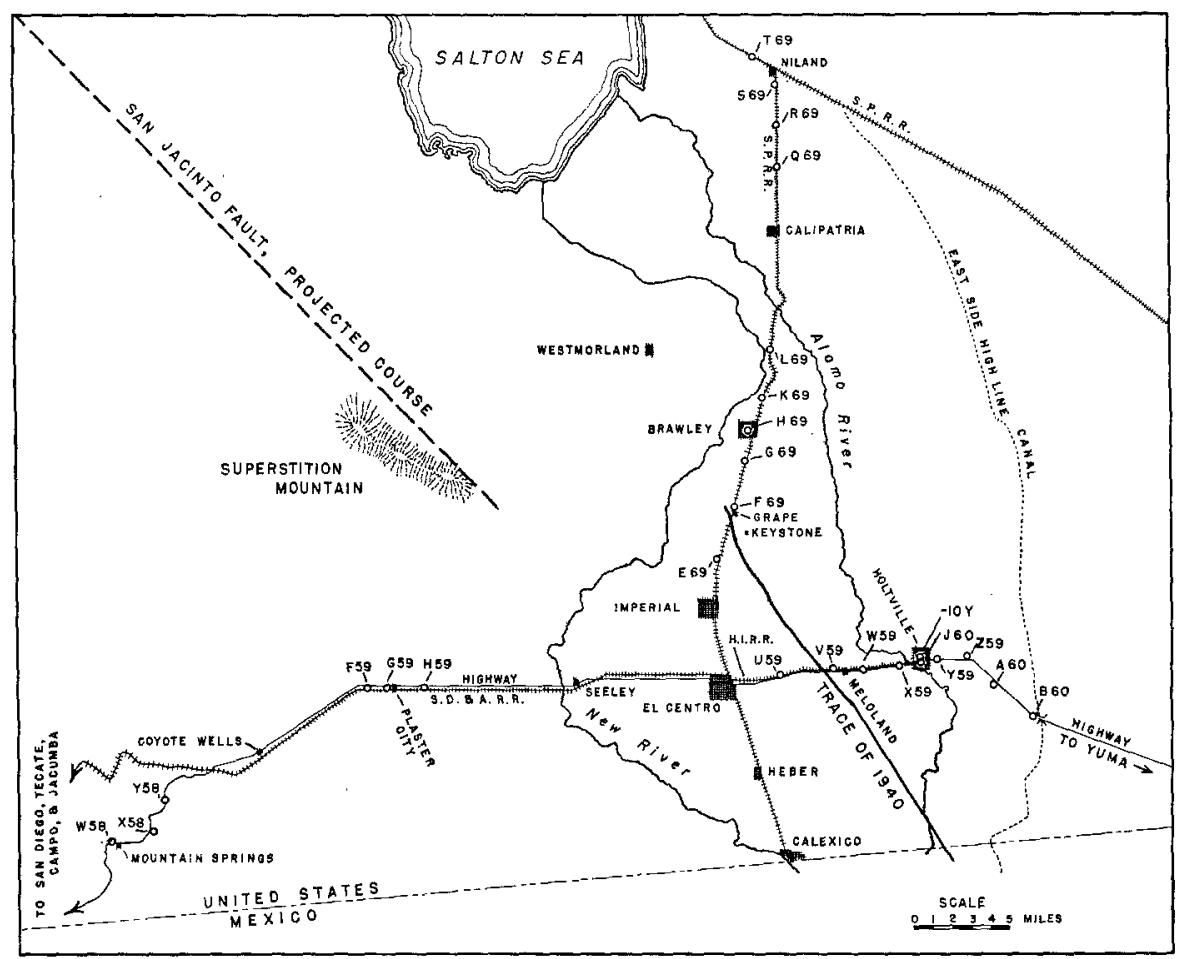

Fig. 1. Map to show location of bench marks and 1940 fault trace.

the fault trace disclosed in 1940. Critical consideration of this relationship is therefore necessary.

Here it will suffice to point out that the general course of this 1940 fault trace, projected northwestward, should pass, at a short distance, to the westward of Brawley and Westmorland. So far as the field evidence noted in 1930 is concerned, the epicenters of the shocks of February 25 and March 1 of that year could be associated with this fault quite as well as with the San Jacinto fault, and with considerable probability much better.

In this connection it must be noted that at its northern end the surface fracture of 1940 exhibits a tendency to swerve to the eastward from its general, 
nearly straight course further to the south. This deviation and possible interpretations of it will be discussed by Buwalda and Richter.

As already stated, the instrumental determinations of the epicenters in 1930 cannot be considered exact. In the absence of adequate instrumental data from the north, around through the east and south to the west, the probable errors are rather large and it is not unlikely that revised locations on, or near to, the 1940 fault trace would fall well within the limits of error.

Consequently the comparison of the intersections (of the 1940 fault outcrop with the lines of leveling) with the places of disturbance to this leveling found in 1931, at and near Brawley and to the west of Holtville, becomes interesting, and possibly important, since the 1930 shocks may well have been due to subsurface activity on this fault zone instead of the San Jacinto zone.

First of all, strong emphasis must be placed upon the fact that there was no previous definite knowledge of this fault, or fault branch, disclosed in 1940. Of course, for decades, it has been recognized that the Imperial Valley is a valley of diastrophism and as such likely to be traversed by as well as bounded by faults-since there is no suggestion of major folding in its development. But the particular line of faulting recently brought to light had never been recognized, nor, so far as is known to the writer, had this exact fracture been suspected. Whether its course could have been suspected, or established, if the district could have been surveyed carefully in 1906 before the ground surface was modified by intensive cultivation, after the specific surface criteria brought to light along the San Andreas fault in the Central California region in 1906 had been recognized and become known, is of course conjectural.

In passing, conjectural too is the question whether the strong earthquake in the Imperial Valley in the afternoon of A pril 18, 1906, originated upon this, or some other, fault or branch. (The great San Francisco shock on April 18, 1906, occurred at 5:12 A.M.) Such meager knowledge as we have would allow correlation of this 1906 shock with the trace developed in 1940 quite as well as with some other line. On the other hand, the existence of other neighboring faults, parallel or subparallel in trend, and indubitably active sources of earthquakes, must also be recognized and kept in mind.

The surface trace of the fault disclosed in 1940 intersects the Southern Pacific Railroad a little more than one-half mile south of the station Grape, formerly Keystone and still shown with this name on some local maps.

However, it must be noted once more that between 5 and 6 miles southeast of this intersection the 1940 fracture of the ground surface began to deviate to the northeastward from the essentially straight course, about $\mathrm{N} 35^{\circ} \mathrm{W}$, it had followed from the United States-Mexican border northwestward to this place of curvature; and where it crossed the railroad south of Grape the horizontal offset was small, not more than 1 foot, probably less. Therefore there is a possibility that this northernmost terminal segment of the 1940 surface break is 
not exactly indicative of the true course of the deep-going fault fracture, but may be of a secondary nature. As stated above, this will be discussed in detail by Buwalda and Richter.

Now the "Diagram showing divergence of 1931 leveling with relation to that of 1926-1927 and of 1928" exhibits disturbance north of bench mark F-69-from above the reference line at F-69 to. a maximum below it at G-69, returning to a point near the reference line at $\mathrm{H}-69$-but south of $\mathrm{F}-69$ no marked suggestion of disturbance is indicated, or discussed by Rappleye. And F-69 is situated at the north end of the switch at Grape (Keystone) (fig. 2), that is, more than one-half mile north of the point where the 1940 fault trace (or its secondary [?] continuation) cuts acroșs the railroad. Further, G-69 is

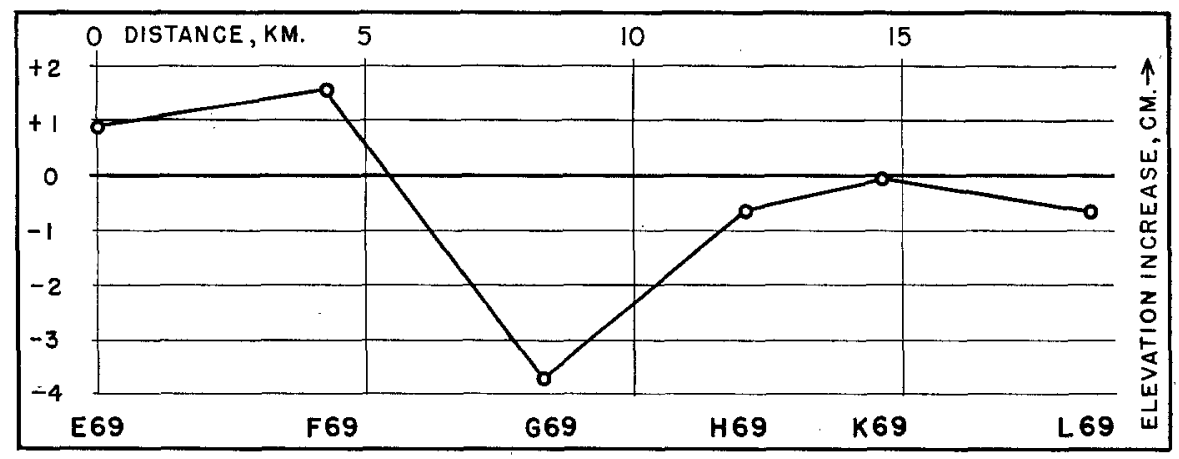

Fig. 2. The zigzag line shows the divergence, in centimeters, above and below the zero or reference line for six bench marks between Calipatria and El Centro. The elevation of bench mark T-69 (see fig. 1), assumed unchanged, is taken as the zero.

more than 3 miles north of this intersection, along the straight course of the railroad, or at least $2 \frac{1}{2}$ miles northeast of the fault trace in direct perpendicular line; and $\mathrm{H}-69$, in Brawley, is about 3 miles from the trace on a direct perpendicular line to northeastward.

However, it should be noted that, according to Ulrich, in 1940, "just north of Grape about 1000 feet of track settled." If the shocks of 1930 were in fact caused by activity on this fault, they too may have produced distortion north of F-69.

The surface trace of 1940 cuts across the highway, and the course of the Holtville Interurban Railway, between El Centro and Holtville, at a point a little more than a mile west of the cross-road, "J" road, near the Meloland school. This point is on the essentially straight portion of the fault trace, and the horizontal offset here, of about 18 inches, suggests strongly that here the trace marks the outcrop of the deep fracture.

Bench mark W-59, about 1 mile east of the Meloland store-hence about 2 miles east of the 1940 trace-Rappleye considered definitely disturbed; and 
in the "Diagram" it stands above the reference line. So also, however, do bench marks U-59 and V-59, situated to the west of W-59 and described above. Disturbance of these was not emphasized by Rappleye (fig. 3 ).

V-59 appears to be situated very near to the fault trace, possibly a little to the east of it; while U-59 appears to be about 2 miles to the west of it.

However, the conspicuous disturbance, as indicated by the "Diagram," lies between bench marks $\mathrm{X}-59$ and $\mathrm{Y}-59$, described above, returning to near normal at Z-59 (fig. 3).

Since Rappleye did not include U-59 and V-59 among the bench marks which he considered disturbed, it seems probable that the departures of thees

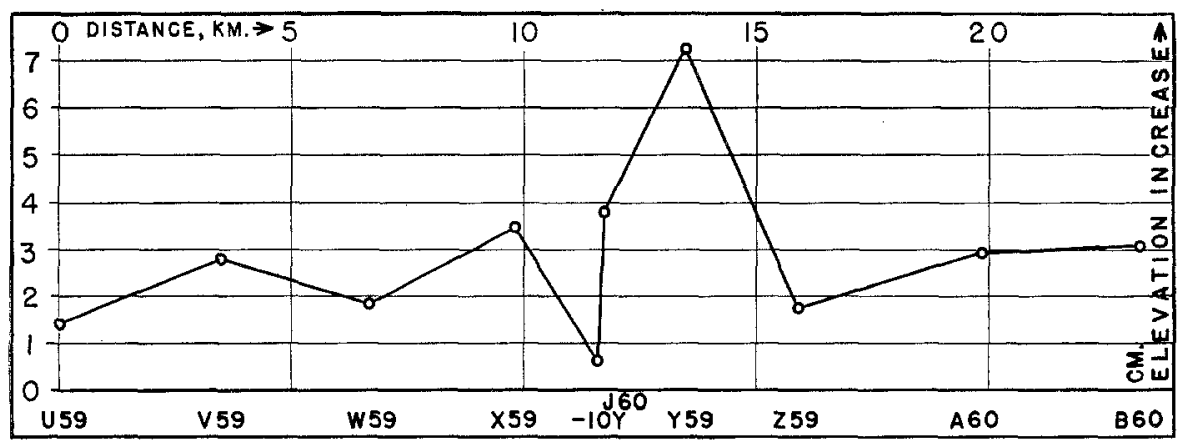

Fig. 3. The zigzag line shows the divergence, in centimeters, above the zero or reference line for the beneh marks between a point to the east of El Centro and the East Highline Canal. The elevation of bench mark $\mathrm{T}-69$ (see fig. 1), assumed unchanged, is taken as the zero.

from the 1927 leveling was judged not greater than the amounts which might be expected from errors in surveying and other usual circumstances.

\section{CORRELATION}

Therefore it is clear that the disturbances to the leveling which may be regarded as significant, found in the 1931 retracement, are situated to the north and east of the 1940 fault trace (in its deviated portion) in the stretch south of Brawley, and to the east, and slightly north, of it (where it is still straight) in the stretch near Holtville and west of that place. Further, the largest departures from the 1927-1928 levels are found about 3 miles away from the fault trace to the north and east in the Brawley stretch and from 4 to 6 miles east (and slightly north) of the trace in the Holtville stretch. As stated previously, the disturbance south of Brawley is near to and east of the banks of the New River. Also the greater departures in the disturbance near Holtville are near to the banks of the Alamo River. In each of these cases the disturbance could quite well be due to slumping and buckling of the water-charged ground near these water courses, an effect of strong shaking often observed in practically all regions where strong earthquakes occur. 


\section{Conchusions}

There are, therefore, three possibilities.

1) It may be a coincidence or an accident that these places of disturbance to leveling found in 1931 are situated near to the trace of the fault disclosed in 1940. But it seems good judgment to regard this as unlikely.

2) The disturbances found in 1931 may have been due directly to surface warping or tilting caused by subsurface slipping in 1930 on this fault first known in 1940. This is possible notwithstanding that the disturbed places lie chiefly, or even wholly, to one side, that to the north and east, of the 1940 fault outcrop; for the zone of fracture must possess some width, and the 1940 trace need not be identical with the projection to the earth surface of a surface of slipping possibly developed in 1930. On the other hand, if surface warping or tilting was produced directly by subsurface dislocation in 1930, it is reasonable to expect that the rock body west of the fault zone would be affected as well as that to the east of it; and there is no reason to suppose that the zone of faulting is several miles wide.

3) The disturbance to the leveling found in 1931 may be a secondary effect due to the shaking experienced in 1930, with buckling or slumping of the waterlogged alluvium near the river banks.

No sure choice can be made among these possibilities. Only a judgment is possible. To the present writer the most probable cause of the change in levels between 1927-1928 and 1931 is the slumping and compaction of the watercharged ground near the surface, with local buckling, due to the vigorous shaking in 1930.

If this judgment should be correct, then the retracement of the levels in 1931 did not serve to detect primary surface warping or tilting due to change in local earth strain, or to fault slipping beneath the surface with change and relief of such strain, in the interval 1927-1928 to 1931.

Of course the gross changes which occurred in 1940 are of a wholly different order.

Notwithstanding the conclusion tentatively stated above, the importance for seismology of accurate surveys, both triangulation and leveling, cannot be too strongly emphasized, pending a time when some superior and less costly method of detecting and measuring the accumulation or release of strain becomes available. More numerous surveys, and more frequent repetition of them, than have been made in the past are necessary. There is at present no substitute for this procedure. Its neglect may prove costly. 


\section{ACKNOWLEDGMENTS}

The writer's indebtedness to the report by Rappleye, and to the Director, and the Chief of the Division of Geodesy, of the U. S. Coast and Geodetic Survey, who made it available to him, is obvious and is gratefully acknowledged. The field work done by the writer, here first discussed in writing, was performed in the service of the Carnegie Institution of Washington in the regular course of the work of the Seismological Laboratory. Indebtedness to his colleagues, Buwalda and Richter, for unpublished information privately communicated is gratefully acknowledged, as well as assistance rendered by Mr. John M. Nordquist and other members of the staff of the Laboratory. Thanks are due to Mr. W. H. Kirkbride, Chief Engineer of the Southern Pacific Company, for information confirming the identity of the former station, Keystone, with the present Grape.

Research Associate in Seismology, Seismological Laboratory, Pasadena, California. 